

\title{
Impact of the North Atlantic Oscillation on Southern Europe Water Distribution: Insights from Geodetic Data
}

Pierre Valty, Olivier de Viron, Isabelle Panet, Xavier Collilieux

\section{To cite this version:}

Pierre Valty, Olivier de Viron, Isabelle Panet, Xavier Collilieux. Impact of the North Atlantic Oscillation on Southern Europe Water Distribution: Insights from Geodetic Data. Earth Interactions, 2015, 19 (10), 10.1175/EI-D-14-0028.1 . hal-01254394

\author{
HAL Id: hal-01254394 \\ https://hal.science/hal-01254394
}

Submitted on 14 Jun 2017

HAL is a multi-disciplinary open access archive for the deposit and dissemination of scientific research documents, whether they are published or not. The documents may come from teaching and research institutions in France or abroad, or from public or private research centers.
L'archive ouverte pluridisciplinaire HAL, est destinée au dépôt et à la diffusion de documents scientifiques de niveau recherche, publiés ou non, émanant des établissements d'enseignement et de recherche français ou étrangers, des laboratoires publics ou privés. 
Earth Interactions - Volume 19 (2015) • Paper No. 10 • Page 1

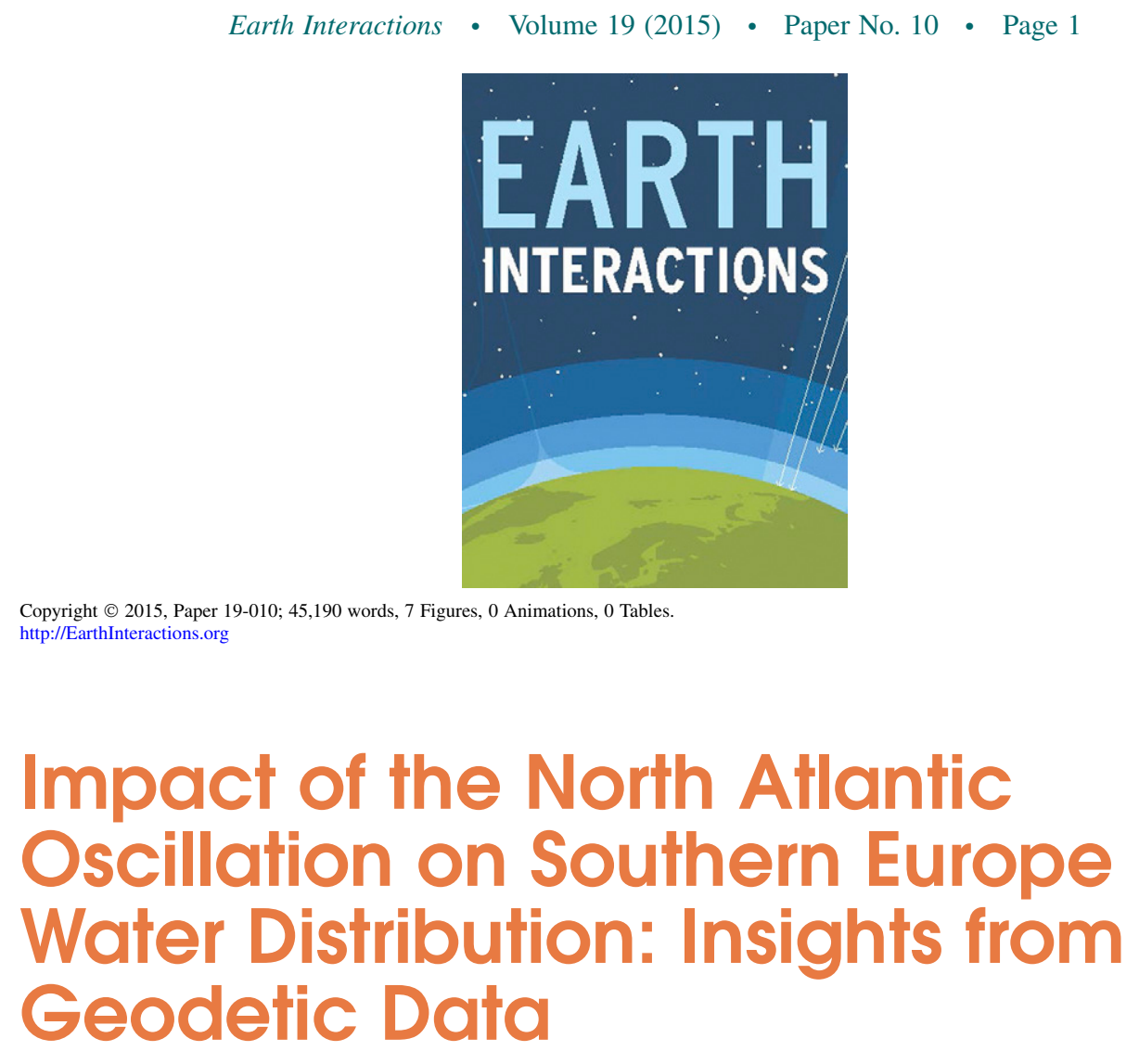

\section{Pierre Valty*}

Institut National de l'Information Géographique et Forestière/Laboratoire de Recherche en Géodésie, Université Paris-Diderot, Paris, France

\section{Olivier de Viron}

Laboratoire Littoral Environnement et Sociétés, Université de la Rochelle, La Rochelle, France

\section{Isabelle Panet and Xavier Collilieux}

Institut National de l'Information Géographique et Forestière/Laboratoire de Recherche en Géodésie, Université Paris-Diderot, Paris, France

Received 22 May 2014; in final form 10 April 2015

ABSTRACT: From space gravity and station position data over southern Europe from 2002 to 2010 , this study investigates the interannual mass

* Corresponding author address: Pierre Valty, Institut National de l'Information Géographique et Forestière/Laboratoire de Recherche en Géodésie, Université Paris-Diderot, bâtiment Lamarck, case 7011, 35 rue Hélène Brion, 75013 Paris, France.

E-mail address: pierre.valty@ign.fr 
Earth Interactions - Volume 19 (2015) - Paper No. 10 • Page 2

redistributions using principal component analysis. The dominant mode, which appears both in gravity and positioning, results from the North Atlantic Oscillation (NAO). This analysis allows us to isolate and characterize the NAO impact on the mass distribution, which appears centered over the Black Sea and its two main catchment basins, the Danube and Dnieper.

KEYWORDS: Europe; Water masses; Global positioning systems (GPS); Interannual variability; North Atlantic Oscillation

\section{Introduction}

Monitoring and modeling Earth's water cycle is a key scientific issue. On land, knowing how water resources evolve and how they respond and interact with the climate variations has a strong societal impact in the context of global change. In particular, the knowledge of the interannual dynamics of water mass redistributions at the regional scale is mandatory to estimate the effects of the global change on the water cycle. At this time scale, in Europe, the zonal atmospheric circulation over the northern Atlantic Ocean dominates the interannual climate variability. The state of this circulation is classically monitored using the North Atlantic Oscillation (NAO) index (Barnston and Livezey 1987). This index is defined as the normalized difference of atmospheric pressure between Iceland and the Azores or Portugal (Barnston and Livezey 1987). The effect of the NAO is mostly sensible during the winter (Greatbatch 2000) but also affects the summer European climate (Folland et al. 2009; Bladé et al. 2011). It strongly impacts the rain and temperature regimes, with a globally warmer and wetter northwestern Europe and a dryer southern Europe during the positive phase and conversely (Hurrell 1995; Greatbatch 2000; Wanner et al. 2001). In particular, central European droughts have also been linked with strong positive NAO phases (López-Moreno and Vicente Serrano 2008).

Unlike its impact on the precipitation, the signature of NAO in water mass distribution is not fully known because of the complex transfer function between precipitation, temperature, and total water mass. The NAO impact on hydrological or oceanic parameters other than the total water mass has been investigated at local or regional scales. For example, Tsimplis et al. (2013), Stanev and Peneva (2001), and Oguz et al. (2006) evidenced significant correlations between the NAO index and the sea level of the Black Sea, whereas others (Tsimplis et al. 2004; Woolf and Tsimplis 2002) conclude the opposite for the same region. In southeastern Europe (Figure 1), the impact of the NAO on hydrological data such as river flows has also been shown, in particular for the Danube-for example, Rîmbu et al. (2002) and I. Mares et al. (2006, meeting presentation)-where this impact has been linked with interannual precipitation over this basin (Mares et al. 2012). Concerning water mass, recent studies have shown a significant NAO impact on the Mediterranean Sea oceanic mass at interannual time scale (Tsimplis et al. 2013; Fenoglio-Marc et al. 2013). However, up to now, such investigations need to be further extended in order to consider the dynamics of the total oceanic and hydrological system over wider areas. For this, the changes in the total water mass, including the atmospheric, hydrological, and oceanic contributions, need to be considered.

Independent information on the water mass displacement can be obtained from geodetic measurements. Geodesy is the part of Earth's sciences involving the measure of Earth's shape, its orientation, and its gravity potential. The water mass 


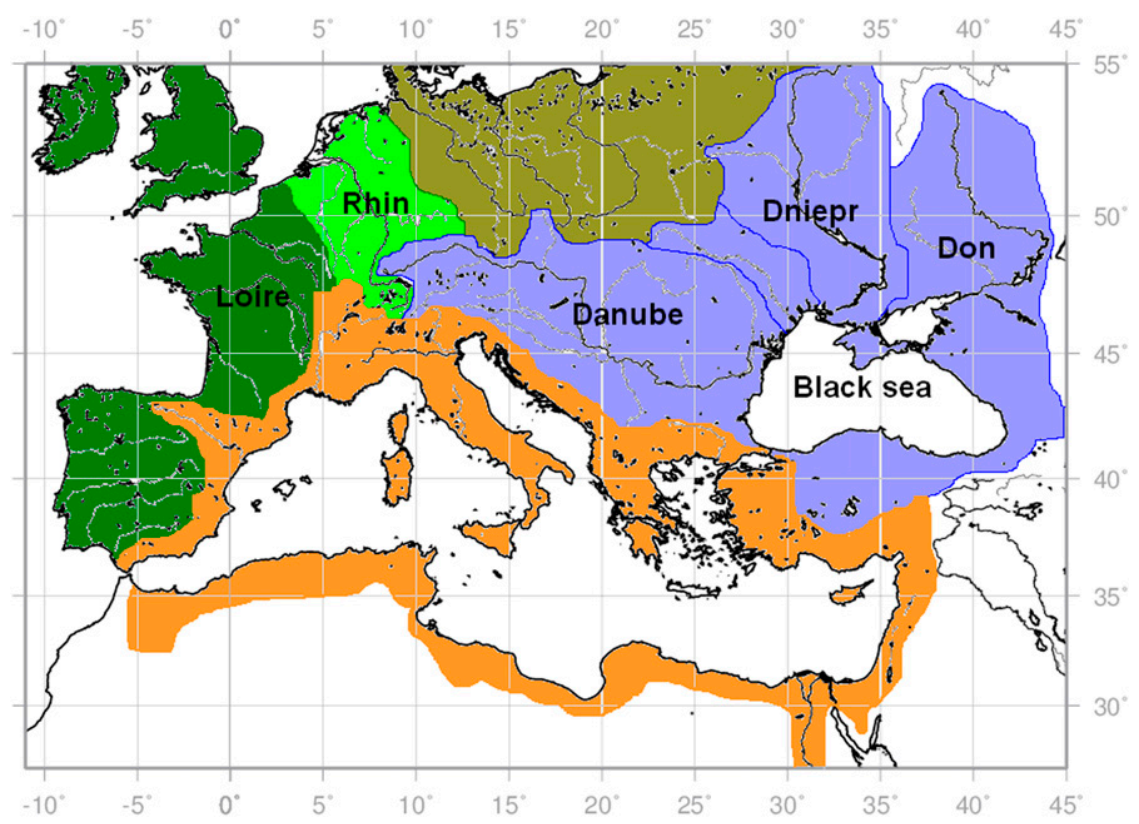

Figure 1. The main river catchment basins in Europe for the Mediterranean Sea (orange), the Atlantic (dark green), the North Sea (light green), and the Black Sea (blue).

load at Earth's surface changes both the gravity and Earth's shape, as the ground bends under the load. At annual (Tregoning et al. 2009; Tesmer et al. 2011) and also interannual time scales (Valty et al. 2013), the water mass distribution is the major source of time variation of Earth's gravity as seen by satellites and of Earth's shape. This makes geodetic data a great tool for understanding the global- and regional-scale water mass redistributions. Moreover, with respect to the classical hydrology dataset, the use of geodesy improves the space distribution of the data. Last, the redundancy obtained when using both GPS and space gravity data allows a more robust identification of the observed phenomena.

Since its launch in 2002, the Gravity Recovery and Climate Experiment (GRACE) space gravimetry mission has been providing unprecedented highquality global data about the time-variable water mass distribution (Tapley et al. 2004; Wahr et al. 2004; Ramillien et al. 2008). Most of those studies focus either on episodic events (Chen et al. 2009, 2010; Swenson and Wahr 2009) or on the seasonal cycle (Güntner 2008). The long-term trend in the mass distribution has also been the topic of studies focusing on the global change effect on water load or on the glacial isostatic adjustment (van den Broeke et al. 2009; Velicogna 2009; Velicogna and Wahr 2013). The interannual dynamics of the water load has also been investigated using GRACE gravity data (Andersen and Hinderer 2005; de Viron et al. 2006; Ramillien et al. 2006; Vey et al. 2012), though to a much lesser extent.

The aim of this paper is to investigate the signature of Northern Atlantic Oscillation on mass redistributions over southern Europe using GRACE and GPS data. This study is organized as follows: in the first section, we describe the geodetic data 
Earth Interactions - Volume 19 (2015) • Paper No. 10 • Page 4

and the models used and their preprocessing. In section 2, we present the principal component (PC) analysis (PCA) method used in this study. In the third section, we investigate the main interannual PCA mode in the geodetic data. Then, in section 4, we compare the interannual water mass variations deduced from geodetic measurements and those deduced from general circulation models (GCMs) and data assimilation products, here both called by the generic term "models." In the last section, we analyze the impact of NAO on southern European interannual water mass changes monitored by geodesy.

\section{Data used and preprocessing}

We use over the 2002-10 period the release 2 (RL02) GRACE geoid models from the Groupe de Recherche en Géodésie Spatiale (GRGS), GPS vertical deformation from a reprocessing of the EUREF Permanent Network (EPN), satellite altimetry multimission data from AVISO, water mass variations from the sum of three models (one atmospheric, one oceanic, and one land hydrology model), and Moderate Resolution Imaging Spectroradiometer (MODIS)-derived sea surface temperature (SST). The preprocessing information directly relevant to our study is described below; the reader is referred to Valty et al. (2013) for more information.

The total GRACE-derived loads and their associated vertical displacements have been reconstructed using Love's theory (Farrell 1972) from the GRGS RL02 models (Bruinsma et al. 2010), assuming in particular that the loads are concentrated at Earth's surface and that Earth's response to loading is elastic. Dealiasing atmospheric and oceanic products are added back in order to recover the total load for the entire water column, including the oceanic and atmospheric contributions. GRACE loads are referred to Earth's center of mass. To compare their associated vertical displacements with the GPS ones, which are referred in Earth's center of figure (CF) as in Tregoning et al. (2009), we introduced a geocenter model that allows the expression of GRACE-associated displacements into the CF. For this, we used geocenter motions from Cheng et al. (2010), first converted into loading spherical harmonics using Equations (4) and (5) of Swenson et al. (2008).

The GPS solution consists of a reprocessing of the EPN data (Bruyninx 2004), performed at the Royal Observatory of Belgium, that we combined with weekly International GNSS Service (IGS) reprocessed solutions (Rebischung et al. 2012) in order to avoid aliasing due to the regional distribution of the EPN stations (Legrand et al. 2012). The six weekly transformation parameters (scale factor is not estimated) between, on the one hand, the IGS and the combined frames and, on the other hand, the EPN and the combined frames were computed under a $0.5-\mathrm{mm}$ constraint between the IGS and the combined geocentric coordinates. The resulting combined frame is thus very close to the IGS frame. The transformation is then applied to all EPN weekly coordinates. The two-step combination strategy used is detailed in Collilieux et al. (2012). The GPS stations with more than $75 \%$ weekly data available during the 2002-10 period have been kept for a total of 110 stations over southern Europe. The possible discontinuities related to earthquakes or equipment changes have been removed. As the signature of the surface load is cleaner in the vertical component of the station displacements (Tregoning et al. 2009; Valty et al. 2013), our study is limited to that component. The origin of the frame in which these vertical displacements are expressed is Earth's center of figure (Collilieux et al. 2012). 
For comparison, we also use outputs from models; the water load is estimated as the sum of the water load computed from the terrestrial water storage provided by the Global Land Data Assimilation System (GLDAS) applied to the Noah model (Rodell et al. 2004) and the water gap hydrology model (Döll et al. 2003) for hydrology, the sum of the load deduced from the ocean bottom pressure (OBP) variations of Mercator model (Ferry et al. 2012) for the ocean (Mediterranean Sea included), and that deduced from the vertical displacements computed by Petrov and Boy (2004) from the National Centers for Environmental Prediction (NCEP) reanalysis (Lee et al. 2002) for the atmosphere. We apply a 500-km-radius Gaussian spatial filtering to these models outputs in order to have a consistent spatial resolution with the load computed from GRACE solutions. The total mass of the models is not constant, as none of the models impose a real mass conservation constraint. This problem is often overcome by adding a constant layer to the models' load in order to keep the total mass constant. Nevertheless, we estimated the maximal value of such a correction to $0.6 \mathrm{~cm}$ of equivalent water height $(\mathrm{EWH})$, which is small with respect to the phenomena investigated here but has to be considered as a possible source of error of the models.

The Black Sea is usually not well modeled or not modeled at all in the ocean models: for example, the ocean bottom pressure variations in this region are not considered in the ECCO model (Fukumori 2002) and, in Mercator, their quality is not assessed because of the peculiar dynamics of this almost closed basin (Y. Drillet 2011, personal communication). Consequently, we estimate the water load over the Black Sea from sea level variations corrected for the thermal expansion contribution and substitute the associated mass load to that from Mercator in the Black Sea. The sea level anomaly (SLA) grids are provided by AVISO through their website (www.aviso.altimetry.fr/fr/donnees/produits). The steric correction is computed using SST. The SST data are derived from Aqua/MODIS infrared measured radiations (Esaias et al. 1998). This estimate of the steric contribution is based on the work from Swenson and Wahr (2007); it assumes that the density changes are related to temperature variations (Chambers et al. 1997; Jayne et al. 2003), that the thermal expansion coefficient is constant and equal to $3 \times 10^{-4} \mathrm{~K}^{-1}$ (Swenson and Wahr 2007), and that all temperature changes occur in the upper layer of the Black Sea, as confirmed by an analysis of sea temperature profiles from the World Ocean Database 2005 (Locarnini et al. 2006) and by several other studies (Kucuksezgin and Pazi 2003; Kara et al. 2008). From these profiles, we estimated the mean depth of the upper Black Sea layer to $30 \mathrm{~m}$. As the temperature decreases fairly linearly from the SST to the bottom layer constant temperature (around $8^{\circ} \mathrm{C}$ in all seasons), we approximated the temperature in that layer to be the mean value between the MODIS-derived SST and the bottom layer temperature.

Hereafter, the surface mass distribution obtained from the GRACE geoids will be referred to as "GRACE mass distribution," the mass distribution deduced from the sum of the global models is referred to as "models outputs," and the GPS station vertical displacements time series are referred to as "deformation data" below.

The NAO index used is the PC-based North Atlantic Oscillation index, as computed by Hurrell et al. (2003) from the National Center for Atmospheric Research (NCAR) sea level pressure.

Trends are filtered out from all the datasets, as they are mainly related in the deformation data to processes not linked to water mass redistributions. We then 




Figure 2. (top) RMS of the (left) interannual vertical GPS displacements and (right) GRACE-derived displacements. (bottom) Correlation between the GPSand GRACE-derived interannual vertical displacements.

compute the interannual time series from the mass, models outputs, and deformations by removing a seasonal composite signal (Hartmann and Michelsen 1989) and then run a 6-month averaging window on the residual time series. We also apply the same 6-month averaging window to the NAO index.

Both GPS- and GRACE-derived interannual vertical displacements show a dispersion between 0.5 and $3 \mathrm{~mm}$ over Europe, with higher values (2.5-3 mm) over central and eastern Europe. The consistency between GRACE and GPS is quite good, even if GPS stations showing the strongest interannual variability are located in central Europe and not, as for GRACE, around the Black Sea (Figure 2). The interannual correlations between GRACE and GPS vertical displacements are higher than 0.5 for $80 \%$ of the stations. In central and eastern Europe, where the strongest interannual variabilities are noticed both for GRACE and GPS, almost all stations have correlations larger than 0.5 .

\section{The principall component analysis}

PCA (Preisendorfer 1988) is a data mining technique that decomposes a set of time series $X_{i}(\lambda, \phi)$ constituting the matrix $\mathbf{X}$ using the eigenvectors (PCs) of their covariance matrix, so that 


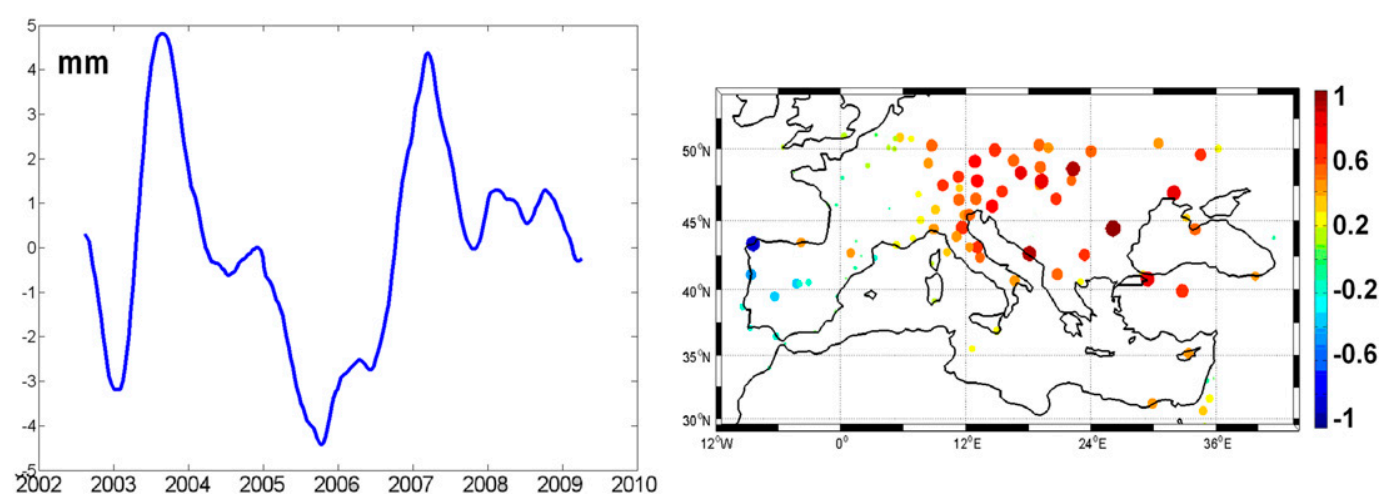

Figure 3. (left) First PC mode time series of interannual GPS vertical displacement (blue). (right) For each station, the amplitude of the first PC mode spatial pattern associated with the GPS interannual displacement.

$$
X_{i}\left(\lambda, \phi, t_{j}\right)=\sum_{k=1}^{N} Y_{k}\left(t_{j}\right) A_{k, i}(\lambda, \phi),
$$

where $\lambda$ and $\phi$ are the longitude and latitude, respectively; $A_{k, i}(\lambda, \phi)$ is the $i$ th component of the $k$ th eigenvector; and $Y_{k}\left(t_{j}\right)$ is the value at time $t_{j}$ of the time series associated with the $k$ th eigenvector. When applied to spatially distributed time series, a PC can be interpreted as a spatial pattern and is associated with a time series that represents the projection of the datasets on this PC. A PC mode is thus the combination of a time series and a map, with the eigenvalue of the PC associated with a percentage of variance explained.

This method has been intensively used in climate studies (e.g., von Storch and Zwiers 1999) and, more recently, in geodesy and gravimetry studies for its ability to retrieve a common signal in a set of noisy time series (Chambers 2006; de Viron et al. 2006; Schrama et al. 2007; de Viron et al. 2008; Rangelova and Sideris 2008; Zerbini et al. 2008; Rieser et al. 2010; Mandea et al. 2012).

\section{Interannual water mass variations common to mass and deformation}

Applying the PCA independently on GPS deformation data and GRACE mass, we obtain two modes for which both the time series and the space patterns are similar for the two datasets. Only the first mode is discussed here.

This first mode captures $41 \%$ of the variance of the GPS deformation and $56 \%$ of the variance of the GRACE-derived mass. The geographical patterns associated with this first mode are shown in the right-side panels of Figure 3 for the GPS deformation data and Figure 4 for the GRACE-derived mass, where it can be seen as quite consistent between GRACE and GPS, even if a few GPS stations are not impacted. It is mostly active in central and eastern Europe, especially around the Black Sea and over the Danube and Dnieper basins (Figure 1), which are discharging into this sea. The time series associated with this first mode from 
Earth Interactions - Volume 19 (2015) - Paper No. 10 • Page 8

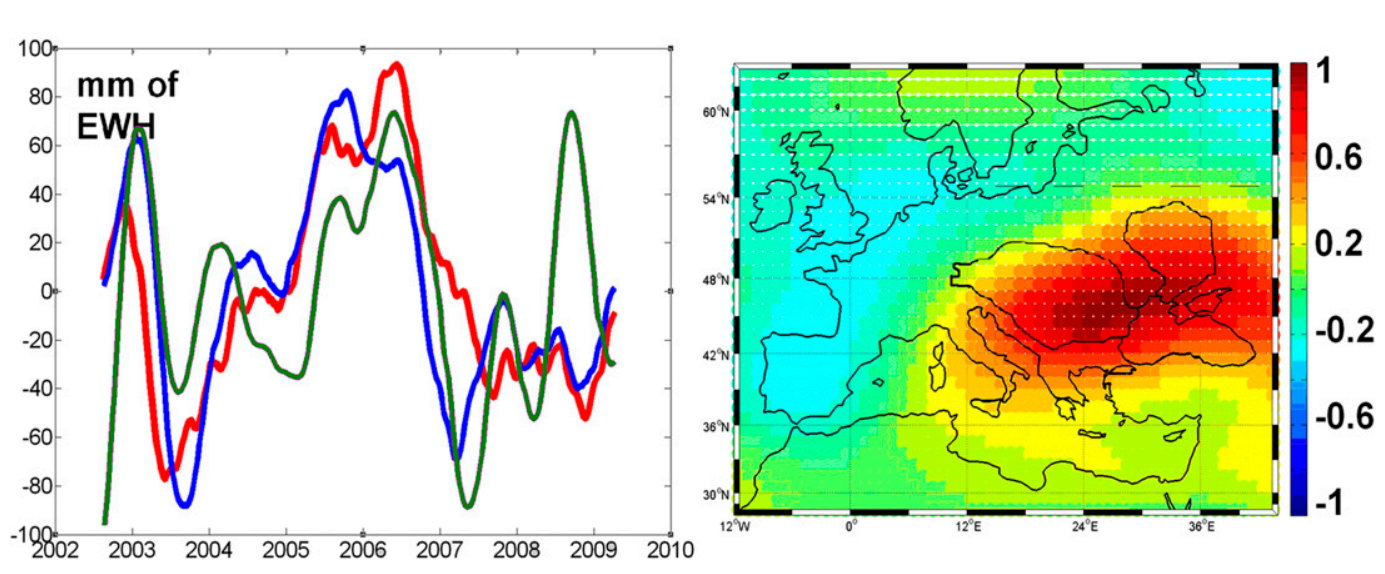

Figure 4. (left) First PC mode time series of interannual GPS vertical displacement, scaled by a negative factor (blue), mode-1 time series of interannual GRACE water load (red), and 6-month filtered NAO, with a 3-month time lag and scaled by a negative factor (green). The negative factors $(-100$ for the NAO and - 18 for the GPS PC mode) have been chosen in order to make easier the comparison between the time series. (right) Amplitude of the first PC mode spatial pattern associated with the GRACE interannual water load.

GRACE-derived mass and GPS deformation (Figure 4, left panel) are significantly anticorrelated at the $95 \%$ level. The peak-to-peak amplitude associated with the mode can reach $9 \mathrm{~mm}$ for vertical displacement and 16-cm EWH for mass. Note that when applying the PCA to GRACE-derived mass at the GPS station locations only, the spatial pattern of the first PC mode (not shown here) is very consistent with that estimated from the GPS displacements (Figure 3, right panel).

The time series associated with this mode for deformation are dominated by the signature of three noticeable climate events: the summer 2003 heatwave (associated with a drought and a negative vertical displacement), the spring 2005 flooding in southeastern Europe, and the winter 2006/07 drought. Only the first two events are also present in the time series for this mode on mass (Figure 4). Indeed, during the winter 2006/07 event, the regional-scale uplift of the GPS stations is consistent with a severe drought in the area, which is confirmed by the Palmer drought severity index (Dai 2011) and by the models outputs (Figure 4), whereas GRACEderived mass shows only a slight minimum.

\section{Comparison between geodesy and model-derived water mass estimates}

The first PC mode computed from the models outputs explains $38 \%$ of the variance. Its associated time series agrees with that of the first PC mode from mass and displacements (Figure 5, left panel). As found by Fenoglio-Marc et al. (2012), both interannual mass changes inferred from GRACE and derived from the models are much stronger in the Black Sea than in the Mediterranean. We compared our 

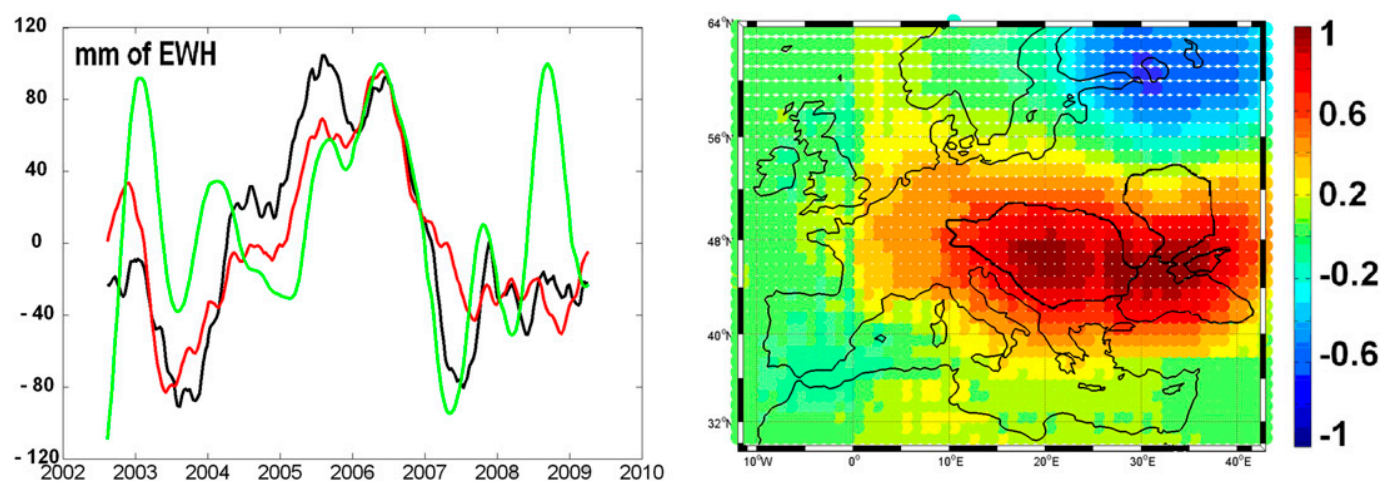

Figure 5. (left) Time series of the first PC of the interannual models' water load (black), time series of the first PC of the interannual GRACE water load (red, the same as in Figure 1), and 6-month filtered NAO, with a 3-month time lag and scaled by a negative factor (green). The negative factor $(-120)$ has been used in order to make easier the comparison between the time series. (right) Mode-1 spatial pattern associated with the models' interannual water load.

results to those of Fenoglio-Marc et al. (2012) and of Aus der Beek et al. (2012), who in particular compared several hydrology models for leakage correction of GRACE-derived mass changes in the Black Sea and in the Mediterranean Sea. We find here a mean correlation above the Black Sea between, from one part, interannual mass changes inferred from GRACE and corrected from land hydrology using GLDAS and, from the other part, interannual mass changes deduced from satellite altimetry and corrected from steric contribution using MODIS-derived SST (Figure 6) is at the same level [0.74 in this study, compared to 0.68 by Fenoglio-Marc et al. (2012) and 0.71 to 0.74 , depending on the hydrology models, for Aus der Beek et al. (2012)]. Both of these studies use a regional modeling based on the Nucleus for European Modelling of the Ocean (NEMO) (Grayek et al. 2010) to correct altimetry from the steric contribution.

However, despite their good general agreement, geodesy and models' outputs slightly disagree on the associated spatial pattern. Indeed, even if the Danube basin and the Black Sea itself participate with the mode for the models' outputs (Figure 5 , right panel), the areas located at the north of the Black Sea, in particular the north of the Dnieper basin, are partly excluded from this first mode, as seen in the models outputs. On the other hand, in the geodetic time series and especially for GRACEderived mass, this basin is fully part of the first mode, slightly shifted toward the north compared to the models.

The slight disagreement between GRACE-derived mass and models' outputs cannot be settled using displacement, as the number of GPS stations in this region is too small. Note that GLDAS theoretically only considers the subsurface water, and the most important differences are mostly localized in the central Dnieper basin, a region with large lakes and very porous soils, likely to host groundwater resources (Gilbrich 2000; Zekster and Everett 2004). Nevertheless, the explanation of this slight shift is not straightforward. The differences between GRACE and 
Earth Interactions - Volume 19 (2015) - Paper No. 10 • Page 10
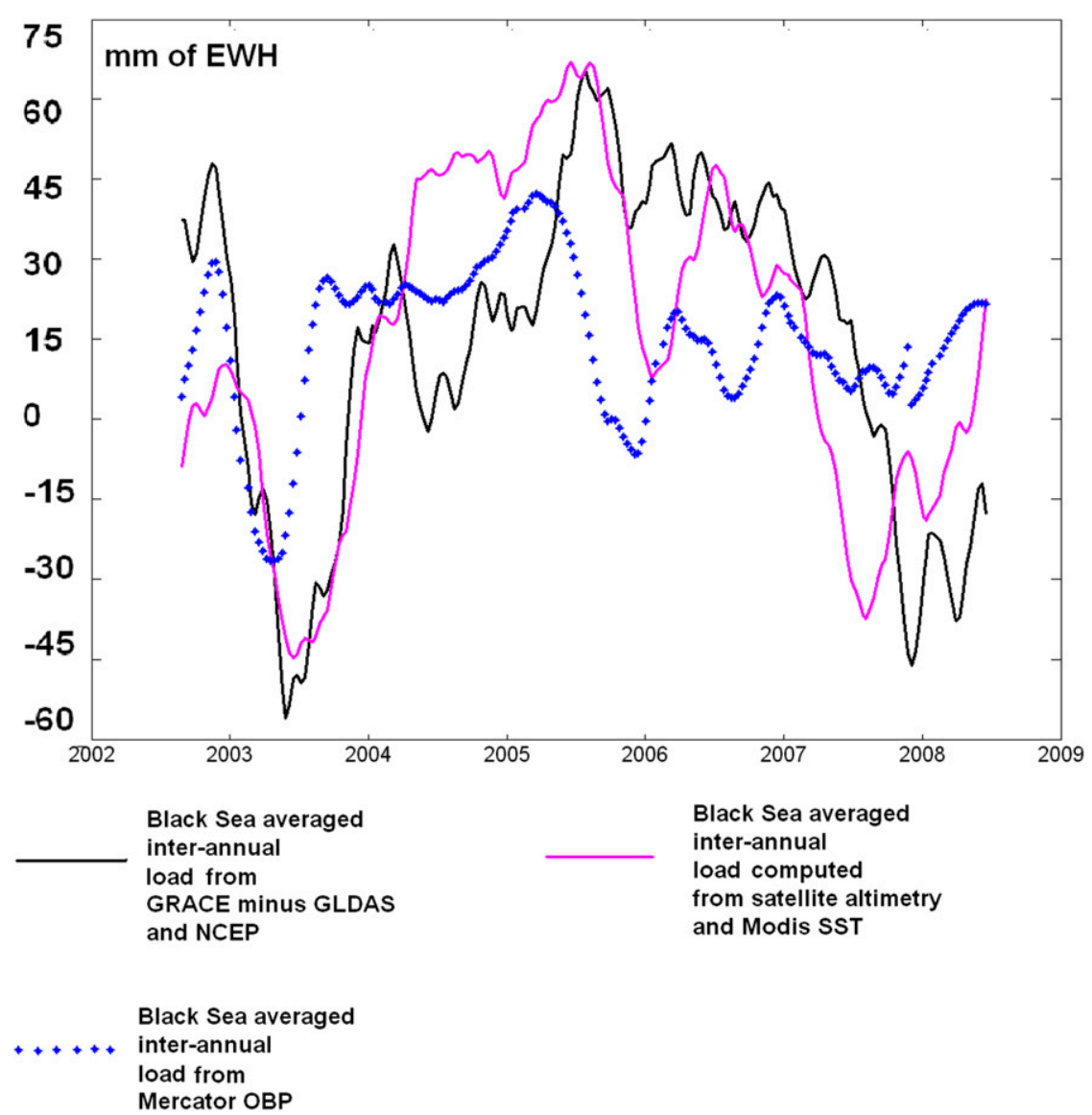

Figure 6. Interannual time series of loading derived from GRACE, corrected from hydrological and atmospheric contributions (black line), from Mercator OBP (blue dashed line) and from satellite altimetry corrected from steric contribution using MODIS-derived sea surface temperature (pink line). The loading is averaged over the Black Sea.

models in the Dnieper basin (between 2- and 6-cm EWH) are too large to be explained by the correction of the nonconservation of the total Earth's mass of the models using a constant mass layer $(0.6-\mathrm{cm}$ EWH). These discrepancies are not smaller when using the WaterGAP Global Hydrology Model (WGHM), which models both surface water and groundwater resources (Döll and Fiedler 2008; Jin and Feng 2013). This would either rule out the hypothesis of contribution from groundwater or surface water or indicate error in modeling those quantities in those regions. Moreover, in Europe, authors such as Springer et al. (2014) have shown that differences in terrestrial water storage between a set of models and GRACE should often come from bias in the precipitation minus evaporation estimate of the models - a bias that can be modeled.

The first mode of the PCA is thus consistent both temporally and geographically between the three estimates used in our study (GRACE, GPS, and models), except for some areas mostly included in the Dnieper basin. 
Earth Interactions - Volume 19 (2015) • Paper No. 10 • Page 11

\section{Impact of the North Atlantic Oscillation on the water distribution in southern Europe}

The time series associated with the first PC mode described in section 3, either in mass or deformation, are significantly (at the 95\% level) correlated with the NAO index. The correlation is larger for a temporal lag of 3 months (Figure 5), which is consistent with the fact that the NAO effects on water load can be delayed by a few months with respect to its precipitation impact, based on the dynamics of the concerned hydrological basins. This correlation coefficient is 0.56 for GPS deformation and -0.51 for GRACE-derived mass. The NAO index and the mode time series nevertheless show episodic disagreements, for example, at the beginning of 2004 or the end of 2008, indicating that mode 1 is the superimposition of NAO and of other secondary effects. To separate the atmospheric effect from the hydrological one, we also made the same analysis after the removal of the atmospheric contribution. Interannual atmospheric loads from the NCEP-NCAR reanalysis, computed with respect to Earth's center of mass, were removed from GRACE total loads (including AOD1B products). In the same way, displacements from the NCEP atmospheric model, computed with respect to Earth's center of figure, were removed from the GPS vertical displacements before computing the interannual signals. Similar results are obtained when removing this atmospheric contribution, and the correlation with NAO is even slightly improved. This is consistent with the atmosphere playing a minor role in that process. Considering that not correcting for the atmospheric effect allows our results to stay as close as possible to the geodetic observation, we decided to only consider and show the results without the atmospheric correction.

Our PCA study shows that the correlations found by Rîmbu et al. (2002) between the NAO and Danube runoff into the Black Sea are part of a larger-scale NAOrelated behavior centered on the Black Sea and its main hydrological basins. The strong link between the NAO and the dynamics of water load fluctuations over the Danube and Dnieper basins during the last decade, as deduced from geodetic measurements, is also confirmed for precipitation (Figure 5). Note that the correlations between NAO and precipitation over these regions have been stronger during the 2002-10 period than during the 1979-2001 period (Figure 7).

NAO appears to have driven the most important water mass changes in southern Europe during the last decade, and its effect on the water load first impacted areas that may seem far away from Atlantic influences. This result can be partly explained by the combination of strongly NAO-related precipitation on the Danube and Dnieper basins, especially during the last decade, and of the large amplitude of the interannual water storage changes in these basins. This amplitude can also be linked with the size of these two hydrological basins that are the two largest in Europe in terms of surface area.

\section{Conclusions}

We have investigated the interannual fluctuations of the water mass in southern Europe by analyzing GRACE data and GPS vertical displacements and comparing them to the load deduced from the sum of models. We show that nearly $50 \%$ of the interannual mass distribution changes are associated, during the 2002-10 period, 

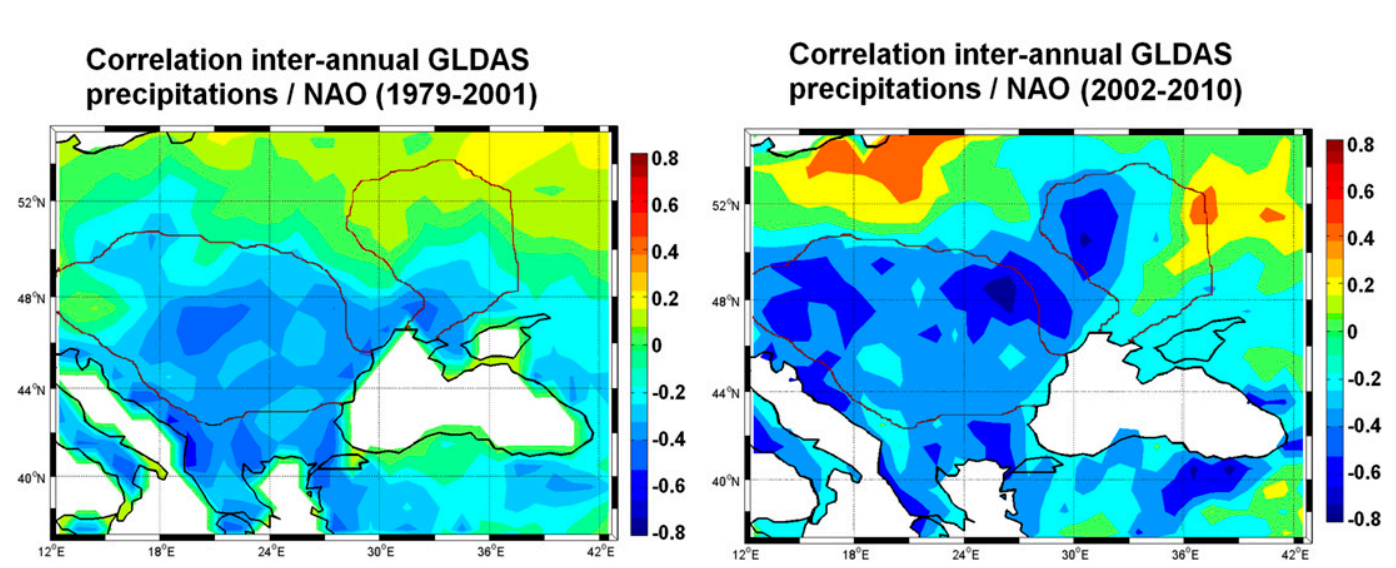

Figure 7. Correlations between the NAO and the interannual precipitation from the GLDAS-Noah model (left) between 1979 and 2001 and (right) between 2002 and 2010.

with a regional-scale mode over the Black Sea and its two major basins, the Danube and the Dnieper, closely related to the North Atlantic Oscillation. This mode is common to GPS vertical displacements and GRACE-derived water load and is the signature of a strong NAO-associated water load variation in some of the southern European basins. This result extends, for example, those variations from Fenoglio-Marc et al. (2012), who also found strong interannual mass changes in the Black Sea, associated with a mass excedent in 2005 and 2006 and a negative mass anomaly in 2003 and 2008.

The models' outputs and geodesy data slightly disagree about the localization of this mode over the Dnieper basin. The explanation of this excess of water associated with the NAO in the Dnieper basin is not identified yet. This study shows the ability of geodetic measurements to be used for climatic studies, especially at interannual time scales, as an independent source of information in complement to the usual climatic datasets.

We provide an independent, geodetic-only assessment of the NAO effect on water mass redistributions over Europe. Our results extend those of Fenoglio-Marc et al. (2013) and Tsimplis et al. (2013), which focused on the Mediterranean Sea, and those of Stanev and Peneva (2001) on the Black Sea. We indeed show that the NAO-related mass changes are not only restricted to the ocean mass but are associated with a regional-consistent behavior in which the precipitation and the size of the hydrological basins could explain a part of the NAO-related mass changes over both the Mediterranean and the Black Seas.

The larger area of our study allows showing that the NAO impact center of water mass changes was shifted to the east compared to its classical impact area on precipitation or temperatures. In addition, as it relies on independent data, it is free from climate-based assumptions. This shows the interest of satellite geodesy for climate studies especially and the interannual time scale.

Acknowledgments. We thank the Royal Observatory of Belgium for providing the weekly GPS Sinex and the Mercator team for providing us the global ocean bottom 
Earth Interactions - Volume 19 (2015) • Paper No. 10 • Page 13

pressure fields. This research was funded by the Centre National d'Etudes Spatiales through the TOSCA committee and by the Institut Universitaire de France. We are also grateful to the two reviewers for their helpful comments.

\section{References}

Andersen, O. B., and J. Hinderer, 2005: Global inter-annual gravity changes from GRACE: Early results. Geophys. Res. Lett., 32, L01402, doi:10.1029/2004GL020948.

Aus der Beek, T., L. Menzel, R. Rietbroek, L. Fenoglio-Marc, S. Grayek, M. Becker, J. Kusche, and E. Stanev, 2012: Modeling the water resources of the Black and Mediterranean Sea river basins and their impact on regional mass changes. J. Geodyn., 59-60, 157-167, doi:10.1016/ j.jog.2011.11.011.

Barnston, A. G., and R. E. Livezey, 1987: Classification, seasonality and persistence of lowfrequency atmospheric circulation patterns. Mon. Wea. Rev., 115, 1083-1126, doi:10.1175/ 1520-0493(1987)115<1083:CSAPOL > 2.0.CO;2.

Bladé, I., B. Liebmann, D. Fortuny, and G. J. van Oldenborgh, 2011: Observed and simulated impacts of the summer NAO in Europe: Implications for projected drying in the Mediterranean region. Climate Dyn., 39, 709-727, doi:10.1007/s00382-011-1195-x.

Bruinsma, S., J.-M. Lemoine, and R. Biancale, 2010: CNES/GRGS 10-day gravity field models (release 2) and their evaluation. Adv. Space Res., 45, 587-601, doi:10.1016/j.asr.2009.10.012.

Bruyninx, C., 2004: The EUREF Permanent Network: A multi-disciplinary network serving surveyors as well as scientists. Geoinformatics, 7, 32-35.

Chambers, D. P., 2006: Observing seasonal steric sea level variations with GRACE and satellite altimetry. J. Geophys. Res., 111, C03010, doi:10.1029/2005JC002914.

_ B. D. Tapley, and R. H. Stewart, 1997: Long-period ocean heat storage rates and basin-scale heat fluxes from TOPEX. J. Geophys. Res., 102, 10 525-10 533, doi:10.1029/96JC03644.

Chen, J. L., C. R. Wilson, B. D. Tapley, Z. L. Yang, and G. Y. Niu, 2009: 2005 drought event in the Amazon River basin as measured by GRACE and estimated by climate models. J. Geophys. Res., 114, B05404, doi:10.1029/2008JB006056.

$\longrightarrow, \ldots$, and -2010 : The 2009 exceptional Amazon flood and interannual terrestrial water storage change observed by GRACE. Water Resour. Res., 46, W12526, doi:10.1029/ 2010WR009383.

Cheng, M. K., J. C. Ries, and B. D. Tapley, 2010: Geocenter variations from analysis of SLR data. Reference Frames for Applications in Geosciences, Z. Altamimi and X. Collilieux, Eds., Vol. 138, International Association of Geodesy Symposia, Springer, 19-25, doi:10.1007/978-3-642-32998-2_4.

Collilieux, X., T. van Dam, J. Ray, D. Coulot, L. Métivier, and Z. Altamimi, 2012: Strategies to mitigate aliasing of loading signals while estimating GPS frame parameters. J. Geod., 86, 114, doi:10.1007/s00190-011-0487-6.

Dai, A., 2011: Characteristics and trends in various forms of the Palmer drought severity index (PDSI) during 1900-2008. J. Geophys. Res., 116, D12115, doi:10.1029/2010JD015541.

de Viron, O., M. Diament, and I. Panet, 2006: Extracting low frequency climate signal from GRACE. eEarth Discuss., 1, 21-36, doi:10.5194/eed-1-21-2006.

_ I. Panet, V. Mikhailov, M. Van Camp, and M. Diament, 2008: Retrieving earthquake signature in GRACE gravity solutions. Geophys. J. Int., 174, 14-20, doi:10.1111/j.1365-246X.2008.03807.x.

Döll, P., and K. Fiedler, 2008: Global-scale modeling of groundwater recharge. Hydrol. Earth Syst. Sci., 12, 863-885, doi:10.5194/hess-12-863-2008.

— , F. Kaspar, and B. Lehner, 2003: A global hydrological model for deriving water availability indicators: Model tuning and validation. J. Hydrol., 270, 105-134, doi:10.1016/ S0022-1694(02)00283-4.

Esaias, W. E., and Coauthors, 1998: An overview of MODIS capabilities for ocean science observations. IEEE Geosci. Remote Sens., 36, 1250-1265, doi:10.1109/36.701076. 
Earth Interactions - Volume 19 (2015) - Paper No. 10 • Page 14

Farrell, W. E., 1972: Deformation of the Earth by surface loads. Rev. Geophys., 10, 761-797, doi:10.1029/RG010i003p00761.

Fenoglio-Marc, L., R. Rietbroeck, S. Grayek, M. Becker, J. Kusche, and E. Stanev, 2012: Water mass variation in Mediterranean and Black Seas. J. Geodyn., 59-60, 168-182, doi:10.1016/ j.jog.2012.04.001.

—, A. Mariotti, G. Sannino, B. Meyssignac, A. Carillo, and M. V. Struglia, 2013: Decadal variability of the net water flux at the Mediterranean Gibraltar Strait. Global Planet. Change, 100, 1-10, doi:10.1016/j.gloplacha.2012.08.007.

Ferry, N., and Coauthors, 2012: GLORYS2V1 global ocean reanalysis of the altimetric era (19932009) at meso scale. Mercator Ocean Quarterly Newsletter, No. 44, Mercator Ocean, Ramonville St. Agne, France, 29-39.

Folland, C. K., J. Knight, H. W. Linderholm, D. Fereday, S. Ineson, and J. W. Hurrell, 2009: The summer North Atlantic Oscillation: Past, present, and future. J. Climate, 22, 1082-1103, doi:10.1175/2008JCLI2459.1.

Fukumori, I., 2002: A partitioned Kalman filter and smoother. Mon. Wea. Rev., 130, 1370-1383, doi:10.1175/1520-0493(2002)130<1370:APKFAS > 2.0.CO;2.

Gilbrich, W. H., 2000: IHME1500—International hydrogeological map of Europe 1:1,500,000. Accessed February 2014. [Available online at www.bgr.bund.de/EN/Themen/Wasser/Projekte/laufend/Beratung/Ihme1500/ihme1500_projektbeschr_en.html.]

Grayek, S., E. V. Stanev, and R. Kandilarov, 2010: On the response of Black Sea level to external forcing: Altimeter data and numerical modelling. Ocean Dyn., 60, 123-140, doi:10.1007/ s10236-009-0249-7.

Greatbatch, R. J., 2000: The North Atlantic Oscillation. Stochastic Environ. Res. Risk Assess., 14, 213-242, doi:10.1007/s004770000047.

Güntner, A., 2008: Improvement of global hydrological models using GRACE data. Surv. Geophys., 29, 375-397, doi:10.1007/s10712-008-9038-y.

Hartmann, D. L., and M. L. Michelsen, 1989: Intraseasonal periodicities in Indian rainfall. J. Atmos. Sci., 46, 2838-2862, doi:10.1175/1520-0469(1989)046<2838:IPIIR>2.0.CO;2.

Hurrell, J. W., 1995: Decadal trends in the North Atlantic Oscillation: Regional temperatures and precipitation. Science, 269, 676-679, doi:10.1126/science.269.5224.676.

— , Y. Kushnir, G. Ottersen, and M. Visbeck, 2003: The North Atlantic Oscillation: Climatic Significance and Environmental Impact. Geophys. Monogr., Vol. 134, Amer. Geophys. Union, 279 pp., doi:10.1029/GM134.

Jayne, S. R., J. Wahr, and F. O. Bryan, 2003: Observing ocean heat content using satellite gravity and altimetry. J. Geophys. Res., 108, 3031, doi:10.1029/2002JC001619.

Jin, S., and G. Feng, 2013: Large-scale variations of global groundwater from satellite gravimetry and hydrological models, 2002-2012. Global Planet. Change, 106, 20-30, doi:10.1016/ j.gloplacha.2013.02.008.

Kara, A. B., A. J. Wallcraft, H. E. Hurlburt, and E. V. Stanev, 2008: Air-sea fluxes and river discharges in the Black Sea with a focus on the Danube and Bosphorus. J. Mar. Syst., 74, 7495, doi:10.1016/j.jmarsys.2007.11.010.

Kucuksezgin, F., and I. Pazi, 2003: Vertical structure of the chemical properties of western Black Sea. Indian J. Mar. Sci., 32, 314-322.

Lee, T., I. Fukumori, D. Menemenlis, Z. F. Xing, and L. L. Fu, 2002: Effects of the Indonesian Throughflow on the Pacific and Indian Oceans. J. Phys. Oceanogr., 32, 1404-1429, doi:10.1175/1520-0485(2002)032<1404:EOTITO>2.0.CO;2.

Legrand, J., N. Bergeot, C. Bruyninx, G. Wöppelmann, A. Santamaria-Gomez, M.-N. Bouin, and Z. Altamimi, 2012: Comparison of regional and global GNSS positions, velocities and residual time series. Geodesy for Planet Earth, S. Kenyon, M. C. Pacino, and U. Marti, Eds., Vol. 136, International Association of Geodesy Symposia, Springer, 95-103, doi:10.1007/978-3-642-20338-1_12.

Locarnini, R. A., A. V. Mishonov, J. I. Antonov, T. P. Boyer, and H. E. Garcia, 2006: Temperature. Vol. 1, World Ocean Atlas 2005, NOAA Atlas NESDIS 61, 182 pp. 
Earth Interactions - Volume 19 (2015) • Paper No. 10 • Page 15

López-Moreno, J. I., and S. M. Vicente-Serrano, 2008: Extreme phases of the wintertime North Atlantic Oscillation and drought occurrence over Europe: A multitemporal-scale approach. J. Climate, 21, 1220-1243, doi:10.1175/2007JCLI1739.1.

Mandea, M., I. Panet, V. Lesur, O. de Viron, M. Diament, and J. L. Le Mouel, 2012: Recent changes of the Earth's core derived from satellite observations of magnetic and gravity fields. Proc. Natl. Acad. Sci. USA, 109, 19 129-19 133, doi:10.1073/pnas.1207346109.

Mares, C., I. Mares, A. Stanciu, and M. Mihailescu, 2012: North Atlantic Oscillation (NAO) influence on the Danube lower basin. Proc. Fifth Int. Scientific Conf. on Water, Climate and Environment: BALWOIS 2012, Ohrid, Macedonia, Balwois, 2012-771. [Available online at http://balwois.com/ $? \mathrm{~s}=\mathrm{NAO}+$ influence $+\mathrm{on}+$ the + Danube + lower + basin\&post_type $=\mathrm{k} 9$ proceeding.]

Oguz, T., J. W. Dippner, and Z. Kaymaz, 2006: Climatic regulation of the Black Sea hydrometeorological and ecological properties at interannual-to-decadal time scales. J. Mar. Syst., 60, 235-254, doi:10.1016/j.jmarsys.2005.11.011.

Petrov, L., and J.-P. Boy, 2004: Study of the atmospheric pressure loading signal in VLBI observations. J. Geophys. Res., 109, B03405, doi:10.1029/2003JB002500.

Preisendorfer, R. W., 1988: Principal Component Analysis in Meteorology and Oceanography. Elsevier, $436 \mathrm{pp}$.

Ramillien, G., A. Lombard, A. Cazenave, E. R. Ivins, M. Llubed, F. Remy, and R. Biancale, 2006: Interannual variations of the mass balance of the Antarctica and Greenland Ice Sheets from GRACE. Global Planet. Change, 53, 198-208, doi:10.1016/j.gloplacha.2006.06.003.

_ J. S. Famiglietti, and J. Wahr, 2008: Detection of continental hydrology and glaciology signals from GRACE: A review. Surv. Geophys., 29, 361-374, doi:10.1007/s10712-008-9048-9.

Rangelova, M., and G. Sideris, 2008: Contributions of terrestrial and GRACE data to the study of the secular geoid changes in North America. J. Geodyn., 46, 131-143, doi:10.1016/j.jog.2008.03.006.

Rebischung, P., B. Garayt, X. Collilieux, and Z. Altamimi, 2012: Reference frame working group coordinator report 2011. International GNSS Service Tech. Rep. 2011, 175-182. [Available online at ftp://igs.org/pub/resource/pubs/2011_techreport.pdf.]

Rieser, D., M. Kuhn, R. Pail, I. Anjasmara, and J. Awange, 2010: Relation between GRACEderived surface mass variations and precipitation over Australia. Aust. J. Earth Sci., 57, 887900, doi:10.1080/08120099.2010.512645.

Rîmbu, N., C. Boroneanţ, C. Buţă, and M. Dima, 2002: Decadal variability of the Danube River flow in the lower basin and its relation with the North Atlantic Oscillation. Int. J. Climatol., 22, 1169-1179, doi:10.1002/joc.788.

Rodell, M., and Coauthors, 2004: The Global Land Data Assimilation System. Bull. Amer. Meteor. Soc., 85, 381-394, doi:10.1175/BAMS-85-3-381.

Schrama, E. J. O., B. Wouters, and D. A. Lavallée, 2007: Signal and noise in Gravity Recovery and Climate Experiment (GRACE) observed surface mass variations. J. Geophys. Res., 112, B08407, doi:10.1029/2006JB004882.

Springer, A., J. Kusche, K. Hartung, C. Ohlwein, and L. Longuevergne, 2014: New estimates of variations in water flux and storage over Europe based on regional (re)analyses and multisensor observations. J. Hydrometeor, 15, 2397-2417, doi:10.1175/JHM-D-14-0050.1.

Stanev, E. V., and E. L. Peneva, 2001: Regional sea level response to global climatic change: Black Sea examples. Global Planet. Change, 32, 33-47, doi:10.1016/S0921-8181(01)00148-5.

Swenson, S., and J. Wahr, 2007: Multi-sensor analysis of water storage variations of the Caspian Sea. Geophys. Res. Lett., 34, L16401, doi:10.1029/2007GL030733.

— and - 2009: Monitoring the water balance of Lake Victoria, East Africa, from space. J. Hydrol., 370, 163-176, doi:10.1016/j.jhydrol.2009.03.008.

_ D. Chambers, and J. Wahr, 2008: Estimating geocenter variations from a combination of GRACE and ocean model output. J. Geophys. Res., 113, B08410, doi:10.1029/2007JB005338.

Tapley, B. D., S. Bettadpur, J. C. Ries, P. F. Thompson, and M. M. Watkins, 2004: GRACE measurements of mass variability in the Earth system. Science, 305, 503-505, doi:10.1126/ science. 1099192. 
Earth Interactions - Volume 19 (2015) • Paper No. 10 • Page 16

Tesmer, V., P. Steigenberger, T. van Dam, and T. M. Gürr, 2011: Vertical deformations from homogeneously processed GRACE and global GPS long-term series. J. Geod., 85, 291-310, doi:10.1007/s00190-010-0437-8.

Tregoning, P., C. Watson, G. Ramillien, H. McQueen, and J. Zhang, 2009: Detecting hydrologic deformation using GRACE and GPS. Geophys. Res. Lett., 36, L15401, doi:10.1029/ 2009GL038718.

Tsimplis, M. N., S. A. Josey, M. Rixen, and E. V. Stanev, 2004: On the forcing of sea level in the Black Sea. J. Geophys. Res., 109, C08015, doi:10.1029/2003JC002185.

— , and Coauthors, 2013: The effect of the NAO on sea level and on mass changes in the Mediterranean Sea. J. Geophys. Res. Oceans, 118, 944-952, doi:10.1002/jgrc.20078.

Valty, P., O. de Viron, I. Panet, M. van Camp, and J. Legrand, 2013: Assessing the precision in loading estimates by geodetic techniques in southern Europe. Geophys. J. Int., 194, 14411454, doi:10.1093/gji/ggt173.

van den Broeke, M., and Coauthors, 2009: Partitioning recent Greenland mass loss. Science, 326, 984-986, doi:10.1126/science.1178176.

Velicogna, I., 2009: Increasing rates of ice mass loss from the Greenland and Antarctic Ice Sheets revealed by GRACE. Geophys. Res. Lett., 36, L19503, doi:10.1029/2009GL040222.

— and limitations of the GRACE satellite data. Geophys. Res. Lett., 40, 3055-3063, doi:10.1002/grl.50527.

Vey, S., H. Steffen, J. Müller, and J. Boike, 2012: Inter-annual water mass variations from GRACE in central Siberia. J. Geod., 87, 287-299, doi:10.1007/s00190-012-0597-9.

von Storch, H., and F. W. Zwiers, 1999: Statistical Analysis in Climate Research. Cambridge University Press, 484 pp.

Wahr, J., S. Swenson, V. Zlotnicki, and I. Velicogna, 2004: Time-variable gravity from GRACE: First results. Geophys. Res. Lett., 31, L11501, doi:10.1029/2004GL019779.

Wanner, H., S. Brönnimann, C. Casty, D. Gyalistras, J. Luterbacher, C. Schmutz, D. B. Stephenson, and E. Xoplaki, 2001: North Atlantic Oscillation-Concepts and studies. Surv. Geophys., 22, 321-382, doi:10.1023/A:1014217317898.

Woolf, D., and M. Tsimplis, 2002: The influence of the North Atlantic Oscillation on sea level in the Mediterranean and the Black Sea derived from satellite altimetry. Proceedings of the Second International Conference on Oceanography of the Eastern Mediterranean and Black Sea: Similarities and Differences of Two Interconnected Basins, TÜBITAK, 145-150.

Zekster, I. S., and L. G. Everett, Eds., 2004: Groundwater Resources of the World and Their Use. IHP-VI, Series on Groundwater 6, United Nations Educational, Scientific and Cultural Organization, $342 \mathrm{pp}$.

Zerbini, S., F. Raicich, V. Gorini, and B. Richter, 2008: Space and time variability of height and gravity in northeastern Italy. Eos, Trans. Amer. Geophys. Union, 89 (Fall Meeting Suppl.), Abstract G51A-0598.

Earth Interactions is published jointly by the American Meteorological Society, the American Geophysical Union, and the Association of American Geographers. Permission to use figures, tables, and brief excerpts from this journal in scientific and educational works is hereby granted provided that the source is acknowledged. Any use of material in this journal that is determined to be "fair use" under Section 107 or that satisfies the conditions specified in Section 108 of the U.S. Copyright Law (17 USC, as revised by P.IL. 94553) does not require the publishers' permission. For permission for any other from of copying, contact one of the copublishing societies. 